\title{
O REFÚGIO NO MUNDO E OS REFUGIADOS NO BRASIL
}

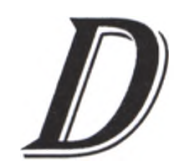

entre as situações dramáticas do mundo das migrações, a dos refugiados constitui, sem dúvida alguma, a mais expressiva. Em primeiro lugar, por tratar-se de um número significativo, cerca de 22,3 milhöes, particularmente da Ásia e da Africa, vitimas da pobreza, das guerras e de inúmeras situaçóes resultantes da violação dos direitos humanos. Em segundo lugar; porque as possibilidades de se conseguir o refúgio definitivo vem se restringindo cada vez mais, em razão do aumento dos pedidos e da crescente xenofobia presente, particularmente em alguns paises europeus.

Se os números não são capazes de expressar o drama vivido por essas pessoas, pelo menos evidenciam a magnitude que a questão dos refugiados vem ganhando neste final de século e de milênio. Na Europa, segundo dados do Alto Comissariado das Nações Unidas para os Refugiados (ACNUR), em 1997 eram mais de 2 milhões os que haviam solicitado asilo politico, sendo que a maioria deles provinha da lugoslávia (550.000), República Democrática da Alemanha (227.000), Azerbaijāo (244.100) e Armênia (219.150).

Em 1999, segundo dados da mesma instituição, os pedidos aumentaram, em razão dos conflitos na região de Kosovo, da problemática dos curdos iraquianos e da crescente imigração proveniente de paises antes pertencentes à antiga Uniâo Soviética. A Alemanha encabeça a lista dos países com o maior número de solicitantes de asilo, seguida pela Inglaterra e pela Suiça.

Vale dizer, no entanto, que o tratamento dado a um refugiado na Europa não é o mesmo dispensado a outro na África. Estimativas apontam que o ACNUR dispendeu 1,23 dólares diários para cada refugiado nos Bálcãs, enquanto na África são gastos apenas 11 centavos de dólar: Em alguns campos de refugiados na Macedônia havia um médico para cada 700 refugiados, já em outros da África a proporção é de apenas um para cada 100 mil. Isto revela que no desigual jogo das relações internacionais, as pessoas são tratadas a partir de critérios meramente políticos, quando não segundo critérios de origem étnica e de nacionalidade.

Diante do quadro aqui traçado, cabe perguntar quais seriam os reflexos desta problemática no Brasil e como este reage a ela. $\dot{E}$ a partir dessa perspectiva que o presente número da Travessia se propóe a abordar os possíveis desdobramentos de tal questão, já que numericamente ela seria pouco expressiva, pois no Brasil, segundo dados da Cáritas, atualmente somam 3.463.

Numa tentativa de analisar uma situação especifica da história das migrações no Brasil, Guillen toma a liberdade de aplicar o conceito de refugiado para o caso dos deslocados compulsoriamente para o trabalho da borracha na Amazônia brasileira, fato este registrado durante a Segunda Guerra Mundial, então denominados "soldados da borracha".

Seguindo a mesma perspectiva, porém abordando o periodo posterior à Segunda Guerra, Paiva procura preencher uma lacuna na história da imigração brasileira, pois naquele periodo, quando se acreditava na cessação dos fluxos imigratórios oriundos da Europa, tivemos a figura dos refugiados de guerra, mão-deobra especializada bem-vinda para alguns setores da economia nacional.

Outros artigos, como os de Petrus, sobre os refugiados angolanos no Rio de Janeiro, e o depoimento de um "zairense" em São Paulo, tomado por Dornelas, trazem-nos a dura realidade vivenciada por estas pessoas na atualidade. E para ilustrar um pouco mais o cotidiano do que é ser um refugiado, Panaro, a partir de sua inserção junto a kosovares na Suiça, apresenta-nos com sutileza as marcas que o exílio inscreve na alma daqueles que na vida um dia experienciaram como horizonte único - a fugaI. Finalmente, Zeledón nos oferece um quadro das açôes voltadas para a assistência e proteção aos refugiados na América Central, onde a situação não é menos dramática e tampouco inexpressiva.

A bem da verdade, todos os artigos relativos à realidade brasileira, alertam-nos não para uma possivel "invasão" de refugiados no território brasileiro, a qual não se vislumbra, pelo menos a curto e médio prazo, mas para uma questão mais ampla, que é a concessão da cidadania aos poucos exilados que acolhemos, em sua maioria do continente africano, em particular angolanos.

Sidney A. da Silua 